\title{
Persistent Peristomal Leakage from Percutaneous Endoscopic Gastrostomy Successfully Treated with Argon Plasma Coagulation
}

\author{
Cláudia Macedo ${ }^{a} \quad$ Nuno Almeida ${ }^{a} b \quad$ Ana Rita Alves ${ }^{c} \quad$ Ana Margarida Ferreira ${ }^{a}$ \\ Pedro Figueiredo ${ }^{a, b}$ \\ ${ }^{a}$ Gastroenterology Department, Centro Hospitalar e Universitário de Coimbra, Coimbra, Portugal; ${ }^{b}$ Faculty of \\ Medicine, University of Coimbra, Coimbra, Portugal; ' ${ }^{\circ}$ Gastroenterology Department, Hospital Distrital da \\ Figueira da Foz, Coimbra, Portugal
}

\section{Keywords}

Percutaneous endoscopic gastrostomy · Peristomal leakage · Argon plasma coagulation

\section{Abstract}

Introduction: Percutaneous endoscopic gastrostomy is a safe and effective technique and its use is widely spread. Peristomal leakage may occur within the first few days after gastrostomy tube placement and also in the mature gastrostomy tract. The initial treatment involves conservative measures. If the leakage does not resolve, different endoscopic interventions could be necessary with consequent impairing of enteral nutrition and, in some cases, the need of creating a new gastro-cutaneous fistula. Case Report: We present 4 consecutive cases complicated with late peristomal leakage and medical treatment failure. These patients underwent upper digestive endoscopy, and circumferential fulguration of the mucosa surrounding the tube with pulsed argon plasma coagulation (APC) at $50 \mathrm{~W}$ and $1 \mathrm{~L} / \mathrm{min}$ flow rate was performed. Additional long through-the-scope clips were applied in 2 cases, since the inner orifice remained enlarged, in order to obtain a better closure. Complete leakage and skin changes resolution occurred between 2 and 6 weeks after the procedure (mean 3.5 weeks). The overall mean follow-up was 19 months after the endoscopic procedure (maximum 30 months, minimum 10 months). There was no recurrence of leakage. Conclusion: The use of APC alone or combined with long through-the-scope clips in large internal stoma orifice resolved persistent leakage from percutaneous endoscopic gastrostomy in all 4 presented cases without complications. In our case series, this technique appeared to be an effective, safe, and relatively lowcost alternative to the treatment of persistent peristomal leakage of the mature gastrostomy tract.

\footnotetext{
(C) 2020 Sociedade Portuguesa de Gastrenterologia Published by S. Karger AG, Basel
}

\section{Extravasamento persistente peri-estoma de gastrostomia endoscópica percutânea tratado com sucesso com coagulação árgon-plasma}

\section{Palavras Chave}

Gastrostomia endoscópica percutânea · Extravasamento peri-estoma · Coagulação árgon-plasma

\section{Resumo}

Introdução: A gastrostomia percutânea endoscópica é uma técnica amplamente usada sendo eficaz e segura. $\mathrm{O}$ extravasamento persistente é uma complicação possível do procedimento podendo ocorrer precocemente ou apresentar-se de forma tardia. $O$ tratamento inicial passa por karger@karger.com www.karger.com/pjg

Karger $\stackrel{\text { ' }}{5}$

BOPEN ACCESS
(C) 2020 Sociedade Portuguesa de Gastrenterologia Published by S. Karger AG, Basel

This article is licensed under the Creative Commons AttributionNonCommercial-NoDerivatives 4.0 International License (CC BYNC-ND) (http://www.karger.com/Services/OpenAccessLicense). Usage and distribution for commercial purposes as well as any distribution of modified material requires written permission.
Cláudia Patrícia Alves de Macedo Gastroenterology Department Centro Hospitalar e Universitário de Coimbra

Praceta Prof. Mota Pinto, PT-3000-075 Coimbra (Portugal) claudia.macedo.07@ hotmail.com 
medidas conservadoras. Se o extravasamento persistir apesar das mesmas, várias intervenções endoscópicas podem ser necessárias com interrupção subsequente da nutrição entérica e nalguns casos pode ser mesmo necessário a criação de uma nova fístula gastro cutânea. Apresentação dos casos: Relato de quatro casos consecutivos complicados com extravasamento persistente tardio e com falência ao tratamento conservador. A todos os doentes foi realizada uma endoscopia digestiva alta com fulguração circunferencial com coagulação árgon-plasma (APC) a 50 Watts e fluxo $1 \mathrm{~L} / \mathrm{min}$. Adicionalmente, em dois casos por presença de orifício interno de grandes dimensões foram aplicados clips longos de modo a obter melhor aproximação dos bordos. Foi conseguida resolução completa do extravasamento e consequentemente das alterações cutâneas em 2 a 6 semanas (média 3,5 semanas). O seguimento após o procedimento foi de 19 meses (máximo 30 meses, mínimo 10 meses). Não se verificaram recorrências do extravasamento. Conclusão: O uso de APC isoladamente ou em combinação com clips longos nos casos de orifício interno de grandes dimensões resolveu o extravasamento persistente após PEG nos quatro doentes sem registo de complicações. Na nossa série, esta técnica parece ser uma alternativa efetiva, segura e de relativo baixo custo para o tratamento do extravasamento persistente tardio.

(0) 2020 Sociedade Portuguesa de Gastrenterologia Publicado por S. Karger AG, Basel

\section{Introduction}

Percutaneous endoscopic gastrostomy (PEG) provides a route for enteral feeding and administration of medication in patients who are likely to have prolonged inadequate or absent oral intake. Since it was first described in 1980 by Ponsky and Gauderer [1, 2], PEG became the modality of choice for long-term enteral access as a result of its safety and effectiveness. Nevertheless, PEG tube placement is associated with potential complications. Most complications of gastrostomy tube placement are minor, such as wound infection or minor bleeding, but major ones (necrotizing fasciitis or colocutaneous fistula) may occur. Peristomal leakage may occur within the first few days after gastrostomy tube placement and also in the mature gastrostomy tract. A persistent leakage beyond the early feeding period substantially reduces patients' and caregivers' quality of life. The reported incidence of peristomal leakage, in a comprehensive clinical review, was $1-2 \%$ [3]. However, the authors hypothesized that this complication is probably much more common, especially early after PEG placement. Indeed, it has been reported to

Persistent Peristomal Leakage from

Percutaneous Endoscopic Gastrostomy be responsible for original PEG tube failure in $7 \%$ of cases in a prospective study [4]. The risk factors associated with persistent peristomal leakage can be patient or wound care related. Diseases and conditions decreasing wound healing ability (diabetes, malnutrition, immunodeficiency), gastrostomy infection, gastric hypersecretion, excessive cleansing with hydrogen peroxide, side torsion on the PEG tube, and lack of external bolster to stabilize the tube are the main risk factors for persistent leakage [5]. In addition, placement of the external bolster of the gastrostomy tube too tightly against the external abdominal wall may lead to poor tissue blood flow, wound breakdown, and peristomal leakage [6]. The initial measures should be the optimization of the patient's medical conditions, loosening of the external bolster, local measures to address skin breakdown (such as powdered absorbing agents or a skin protectant such as zinc oxide ointment), and institution of antisecretory therapy $[3,7,8]$. Replacing the original PEG tube with a larger one should be avoided as this may cause the tract to enlarge and exacerbate the leakage [9]. If the leakage does not resolve with these conservative measures and the gastrostomy tract has had time to mature (usually up to 4 weeks after placement), it is recommended to remove the tube for $24-48 \mathrm{~h}$ allowing partial closure of the tract [10]. Subsequently, a replacement gastrostomy tube can then be placed through the same tract generally when there is at least $50 \%$ closure $[6,10]$. Since different tracts will close at different rates, leaving a guidewire in place may help maintain tract patency until a replacement gastrostomy tube is inserted [6]. If all else fails, the PEG tube should be removed and a new PEG tube placed at a different site. These approaches may imply various endoscopic interventions with consequent impairing of enteral nutrition and, in some cases, the necessity of creating a new gastro-cutaneous fistula. To overcome this problem, in 4 consecutive cases complicated with late peristomal leakage who failed medical treatment, a new endoscopic treatment involving argon plasma coagulation (APC) was tried.

\section{Case Reports}

\section{Case Presentation Number 1}

The patient was a 45 -year-old female with cerebral palsy fed by PEG for 12 years. The last 3 years of follow-up were marked by multiple recurrences to the emergency department due to accidental tube exteriorization, early tube deterioration, and episodes of duodenal tube migration. Ten years after PEG placement, the patient presented with persistent peristomal leakage conditioning exuberant skin changes manifested in the form of erythema and skin maceration. 


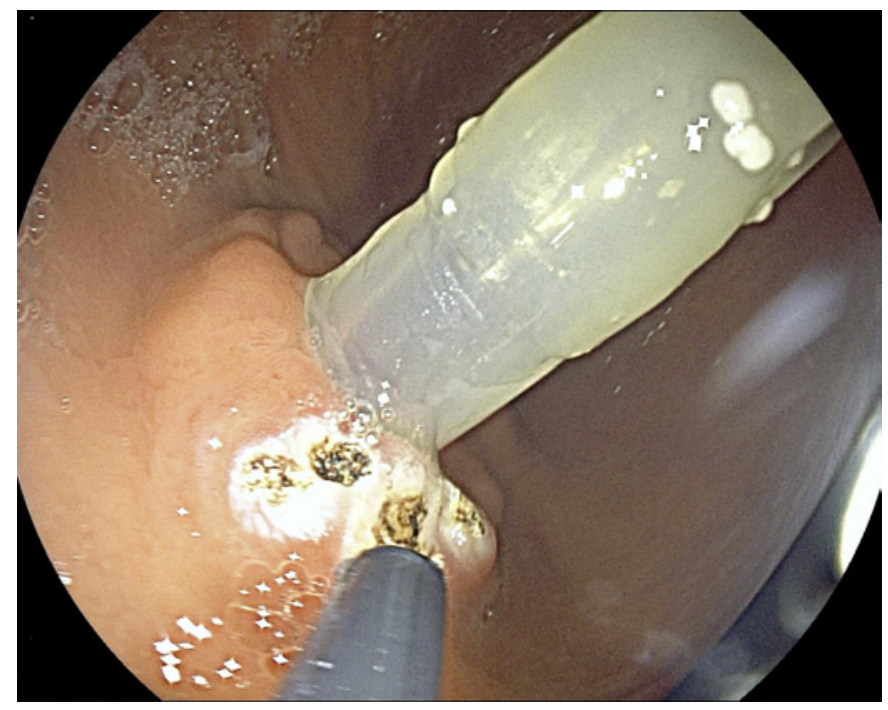

Fig. 1. Circumferential fulguration, without removing the tube, with pulsed argon plasma coagulation at $50 \mathrm{~W}$ and $1 \mathrm{~L} / \mathrm{min}$ flow rate of the internal orifice borders.

Case Presentation Number 2

The patient was a 77-year-old man fed by PEG for 6 years due to neurological dysphagia (amyotrophic lateral sclerosis). Four years after PEG placement, the first signs of leakage were noticed by the presence of cutaneous erythema. Two hospitalizations were recorded (4 and 5 years after PEG placement) because of abdominal wall cellulitis secondary to persistent leakage. After that, during follow-up several episodes of tube deterioration, accidental exteriorization, and duodenal migration were noted.

\section{Case Presentation Number 3}

The patient was a 35-year-old man with cerebral palsy fed by PEG for 10 years. There was registration of just 1 accidental tube exteriorization during the entire follow-up. Nine years after PEG placement, the patient presented with sustained complaints of leakage persisting for 6 months, causing erythema and skin maceration.

\section{Case Presentation Number 4}

The patient was a 58-year-old man fed by PEG in the context of oropharyngeal cancer with ganglionic metastasis. The patient was submitted to induction chemotherapy, and 2 months after PEG placement, he presented with persistent leakage complicated with erythema and superficial ulceration of the surrounding skin.

In all 4 cases, the conservative measures with gastrostomy tube stabilization, zinc-based ointment, and optimization of proton inhibitors use (maximum dose twice a day for at least 3 months) were attempted but without success. These measures were attempted for 4-9 months (mean 5.8 months). After conservative measures failure, the therapeutic possibilities were explained and discussed with all patients and/or legal guardians, and they accepted this therapeutic modality.

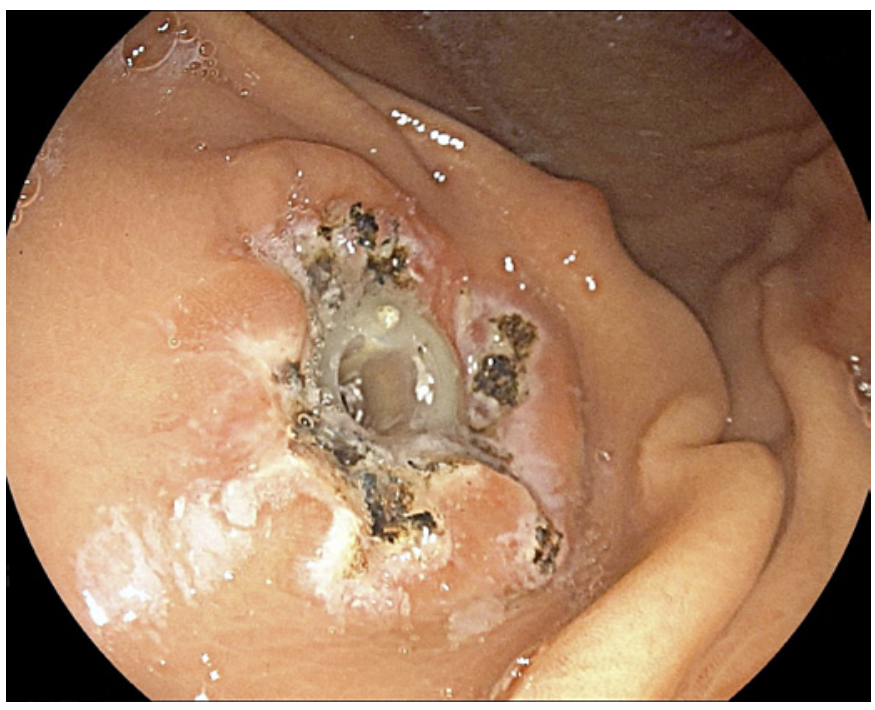

Fig. 2. Circumferential fulguration, without removing the tube, with pulsed argon plasma coagulation at $50 \mathrm{~W}$ and $1 \mathrm{~L} / \mathrm{min}$ flow rate of the internal orifice borders.

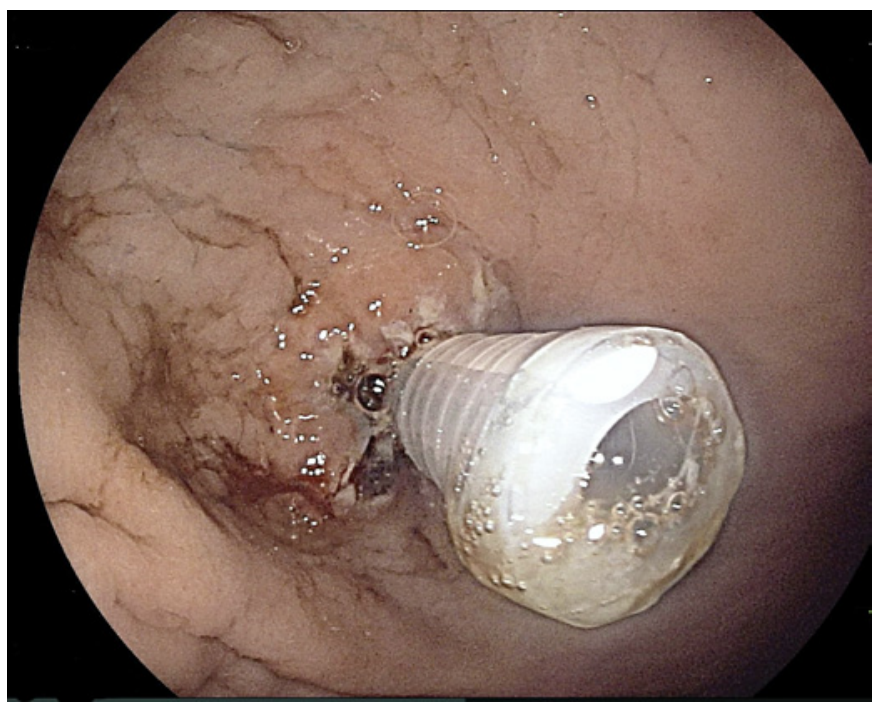

Fig. 3. Tube removal and replacement by a new one of low profile.

\section{Description of the Technique}

The patients were admitted on the day of the procedure. An upper digestive endoscopy under deep sedation administered by anesthesiologists was performed in all 4 patients. The first step was the identification of the internal orifice of the stoma that was enlarged in all of them. Circumferential fulguration of the mucosa surrounding the tube with pulsed APC at $50 \mathrm{~W}$ and $1 \mathrm{~L} / \mathrm{min}$ flow rate was performed (Fig. 1,2). The second step was tube removal and replacement by a new one with the same diameter but button 


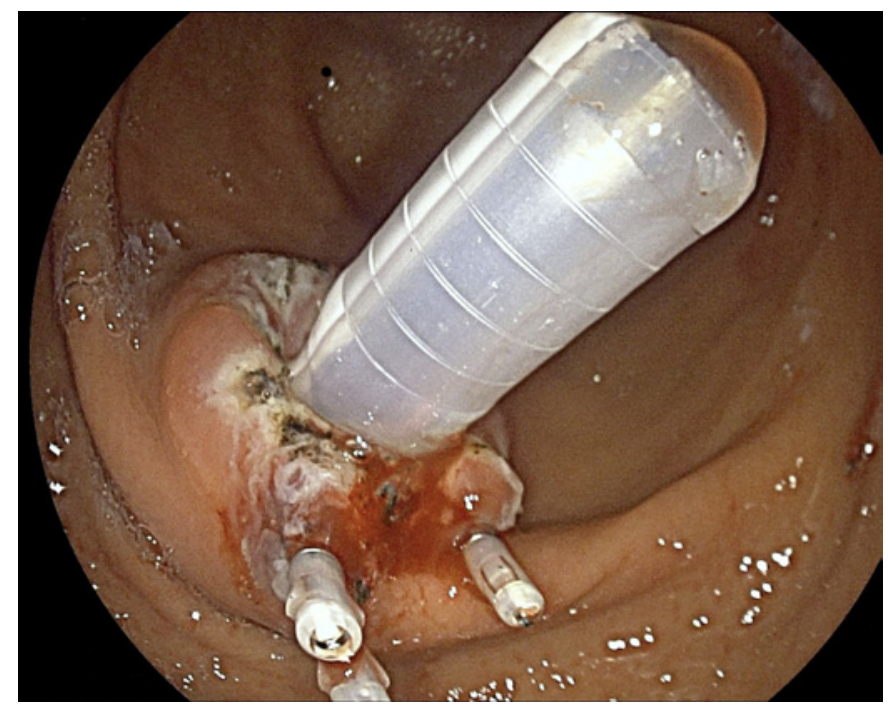

Fig. 4. Application of 3 long through-the-scope clips to obtain a better closure in a larger internal orifice.

model (Fig. 3). In 2 cases (cases number 1 and 4), 3 long throughthe-scope clips were additionally applied, since the caliber of the inner orifice remained enlarged (Fig. 4), in order to obtain a better closure. After the procedure, the patients were kept under clinical surveillance for $24 \mathrm{~h}$. Diet through the PEG was reintroduced 4-6 $\mathrm{h}$ after the procedure with water and ice tea. A cold liquid diet was given $8 \mathrm{~h}$ after the procedure, and on the day of discharge, the patient's usual diet was administered. There were no immediate or late complications.

Complete leakage and skin changes (Fig. 5) resolution occurred between 2 and 6 weeks after the procedure (mean 3.5 weeks). The overall mean follow-up was 19 months after the endoscopic procedure (maximum 30 months, minimum 10 months). There was no recurrence of leakage.

\section{Discussion}

Conservative measures in late leakage often prove unsuccessful, making the removal of the tube and replacement with a new one in the partially closed tract necessary. However, the chronic enlargement of the gastrostomy creates difficulties for the partial closure of the tract. Although, instinctively, placement of increasingly larger-diameter PEG tubes could be an option, this is not advised because it leads to a larger size of the gastrostomy and worsening of leakage [9]. The failure to achieve partial closure culminates in the need of a new PEG tube placement at a different site. In addition, it creates a new problem if full closure of the first PEG tube site is not achieved in a population already at increased risk for surgical procedures. However, it is worth mentioning that in high-risk

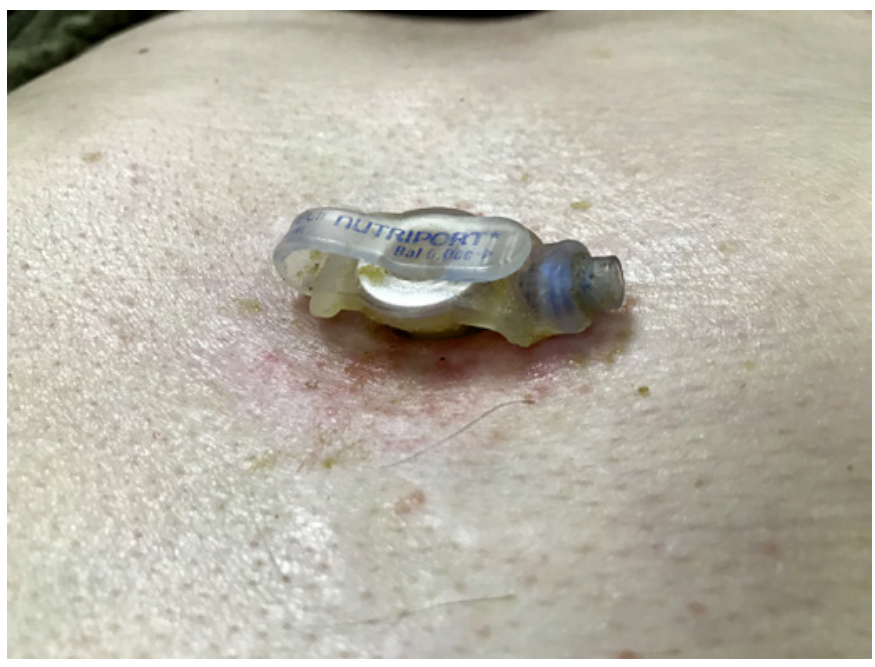

Fig. 5. Complete resolution of leakage and skin changes.

patients an alternative to surgery could be the endoscopic closure from inside using an over-the-scope clip or a fistula plug [11]. Nevertheless, new endoscopic approaches are needed to solve the persistent leakage problem. In 2013, Stanich et al. [12] reported a successful method using an endoscopic suturing device. It was a modification of a technique previously described for closure of nonhealing gastro-cutaneous fistulas occurring after PEG removal $[13,14]$. Still, for the nonhealing gastro-cutaneous fistula problem, Duddempudi et al. [15] reported a combination of electrochemical cautery and endoscopic clip procedure achieving success in 9 out of 11 patients. The choice of the procedure was based on a report of successful closure of a chronic gastro-cutaneous fistula in 3 children and a closure of esophago-pleural fistula using electrocoagulation and endoscopic clips $[16,17]$. The authors argued that electrical and chemical cauterization result in de-epithelialization of the tract, promoting superficial inflammation and leading to bridging scar formation and ultimately healing [15]. Based on these successful case reports, we hypothesized that the use of cauterization with APC could achieve the same results in patients with persistent leakage. APC is a noncontact thermal method resulting in tissue damage of limited depth that leads to successful ablation of superficial layers [18]. Superficial ulceration occurs following APC, which typically heals within 2-3 weeks through a process of mucosal de-epithelization and subsequent fibrosis. Since patients with persistent peristomal leakage have an enlarged stoma, applying APC on the internal orifice allowed the mucosal alterations dis- 
cussed above, reducing its caliber due to fibrosis and consequently resolving the leakage. In the 2 cases with larger internal orifice, we used long through-the-scope clips in order to approximate the walls, performing a combined technique as described by Duddempudi et al. [15] for nonhealing gastro-cutaneous fistulas. Replacement of the old tube by a new one after the fulguration was made since there was some possibility of tube damage, namely the internal bolster, during APC.

\section{Conclusion}

The use of APC alone or combined with long throughthe-scope clips in large internal stoma orifice resolved persistent leakage from PEG in all 4 presented cases without complications. In our case series, this technique appeared to be an effective, safe, and relatively low-cost alternative to the treatment of persistent peristomal leakage of the mature gastrostomy tract. Nevertheless, further comparative studies are needed to confirm this and to understand whether this approach could be an alternative endoscopic therapy for the resolution of persistent peristomal leakage.

\section{Statement of Ethics}

Written informed consent was obtained from the patients and/ or legal guardian to publish their cases.

\section{Conflict of Interest Statement}

The authors declare no conflicts of interest.

\section{Funding Sources}

There are no funding sources.

\section{Author Contributions}

Cláudia Macedo was responsible for the data acquisition and editing, manuscript writing, and reviewed the literature. Nuno $\mathrm{Al}$ meida and Ana Rita Alves were responsible for the data acquisition and reviewed the manuscript. Ana Margarida Ferreira and Pedro Figueiredo reviewed the manuscript.

\section{References}

1 Gauderer MW, Ponsky JL, Izant RJ Jr. Gastrostomy without laparotomy: a percutaneous endoscopic technique. J Pediatr Surg. 1980 Dec;15(6):872-5.

2 Ponsky JL, Gauderer MW. Percutaneous endoscopic gastrostomy: a nonoperative technique for feeding gastrostomy. Gastrointest Endosc. 1981 Feb;27(1):9-11.

3 Schrag SP, Sharma R, Jaik NP, Seamon MJ, Lukaszczyk JJ, Martin ND, et al. Complications related to percutaneous endoscopic gastrostomy (PEG) tubes. A comprehensive clinical review. J Gastrointestin Liver Dis. 2007 Dec;16(4):407-18.

4 Koulentaki M, Reynolds N, Steinke D, Tait J, Baxter J, Vaidya K, et al. Eight years' experience of gastrostomy tube management. Endoscopy. 2002 Dec;34(12):941-5.

5 McClave SA, Chang WK. Complications of enteral access. Gastrointest Endosc. 2003 Nov;58(5):739-51.

6 DeLegge MH, Saltzman JR, Robson KM. Gastrostomy tubes: Complications and their management. Post TW, ed. UpToDate [Internet]. Waltham, MA: UpToDate Inc.; [cited 2020 May 26]. Available from: https://www. uptodate.com

7 Lin HS, Ibrahim HZ, Kheng JW, Fee WE, Terris DJ. Percutaneous endoscopic gastrostomy: strategies for prevention and management of complications. Laryngoscope. 2001 Oct; 111(10):1847-52.

8 Lynch CR, Fang JC. Prevention and management of complications of percutaneous endoscopic gastrostomy (PEG) tubes. Pract Gastroenterol. 2004;28(11):66-76.

9 Schapiro GD, Edmundowicz SA. Complications of percutaneous endoscopic gastrostomy. Gastrointest Endosc Clin N Am. 1996 Apr;6(2):409-22.

10 Tsang TK, Eaton D, Falconio MA. Percutaneous ostomy dilation: a technique for dilating the closed percutaneous endoscopic gastrostomy sites and reinserting gastrostomies. Gastrointest Endosc. 1989 Jul-Aug;35(4): 336-7.

11 Tang S. Endoscopic Management of Gastrocutaneous Fistula Using Clipping, Suturing, and Plugging Methods. Video Journal and Encyclopedia of GI Endoscopy. 2014;2(2):5560.

12 Stanich PP, Sklaw B, Krishna SG. Persistent peristomal leakage from percutaneous endoscopic gastrostomy successfully treated with endoscopic suturing. Endoscopy. 2013;45(S 02 Suppl 2 UCTN):E394.

13 Armengol-Miro JR, Dot J, Abu-Suboh Abadia M, Masachs M, Salord JC, Armengol Bertroli
J, et al. New endoscopic suturing device for closure of chronic gastrocutaneous fistula in an immunocompromised patient. Endoscopy. 2011;43(S 02 Suppl 2 UCTN):E403-4.

14 Kantsevoy SV, Thuluvath PJ. Successful closure of a chronic refractory gastrocutaneous fistula with a new endoscopic suturing device (with video). Gastrointest Endosc. 2012 Mar; 75(3):688-90.

15 Duddempudi S, Ghevariya V, Singh M, Krishnaiah M, Anand S. Treatment of persistently leaking post PEG tube gastrocutaneous fistula in elderly patients with combined electrochemical cautery and endoscopic clip placement. South Med J. 2009 Jun;102(6):585-8.

16 Teitelbaum JE, Gorcey SA, Fox VL. Combined endoscopic cautery and clip closure of chronic gastrocutaneous fistulas. Gastrointest Endosc. 2005 Sep;62(3):432-5.

17 van Bodegraven AA, Kuipers EJ, Bonenkamp HJ, Meuwissen SG. Esophagopleural fistula treated endoscopically with argon beam electrocoagulation and clips. Gastrointest Endosc. 1999 Sep;50(3):407-9.

18 Watson JP, Bennett MK, Griffin SM, Matthewson $\mathrm{K}$. The tissue effect of argon plasma coagulation on esophageal and gastric mucosa. Gastrointest Endosc. 2000 Sep;52(3):3425. 